\title{
Engagement of Russian Mental Health Professionals in the Development of WHO's ICD-11
}

\author{
Вовлечение российских специалистов в области психического здоровья \\ в разработку МКБ-11 ВО3 \\ doi:10.17816/CP79
}

\begin{abstract}
(C) Tahilia J. Rebello', Maya A. Kulygina², Valery N. Krasnov ${ }^{3}$, Kathleen M. Pike', Geoffrey M. Reed ${ }^{1}$ ${ }^{1}$ Department of Psychiatry, Columbia University, Vagelos College of Physicians and Surgeons and WHO Collaborating Center for Capacity Building and Training in Global Mental Health, Columbia University, New York, NY, USA; ${ }^{2}$ Training and Research Centre, Mental-health clinic No.1 named after N.A. Alekseev, Moscow, Russia; ${ }^{3}$ Moscow Research Institute of Psychiatry - a branch of the V. Serbsky National Medical Research Centre of Psychiatry and Narcology of the Ministry of Health of the Russian Federation, Moscow, Russia
\end{abstract}

\author{
(C) Тахилия Дж. Ребелло', Майя А. Кулыгина², \\ Валерий Н. Краснов ${ }^{3}$, Кэтлин М. Пайк ${ }^{1}$, \\ Джеффри М. Рид ${ }^{1}$ \\ ${ }^{1}$ Кафедра психиатрии Высшей медицинской школы \\ Вагелоса и Сотрудничающий центр ВОЗ по устойчивому \\ развитию и обучению в области глобального \\ психического здоровья, Колумбийский университет, \\ Нью-Йорк, штат Нью-Йорк, США; \\ ${ }^{2}$ Научно-образовательный чентр, Психиатрическая \\ клиническая больница №1 им. Н.А. Алексеева, Москва, \\ Россия; ${ }^{3} О$ даел клинико-патогенетических исследований, \\ Московский научно-исследовательский институт \\ психиатрии - филиал Национального медицинского \\ исследовательского центра психиатрии и наркологии \\ им. В.П. Сербского Минздрава России, Москва, Россия
}

\section{ABSTRACT}

The World Health Organization (WHO) has officially approved the next version of its global diagnostic system, the International Classification of Diseases and Related Health Problems, Eleventh Revision (ICD-11). Processes to implement the ICD-11 are now underway. Developing the ICD-11 chapter on Mental, Behavioural and Neurodevelopmental Disorders, in line with WHO's core priorities to enhance the clinical utility, reliability, and global applicability of the guidelines, necessitated a large-scale scientifically-rigorous research program. Such a program of global field studies engaged mental health professionals from across the world, with substantial contributions from clinicians in the Russian Federation.

This paper systematically highlights the substantive roles played by Russian clinicians in all steps of development of the mental, behavioural, and neurodevelopmental disorder guidelines, including their participation in the following: 1) early formative field studies that informed the organizing principles and overarching structure of the ICD-11; 2) large-scale online studies that used a case-controlled methodology to evaluate the guideline's clinical utility and the accuracy with which the new ICD-11 guidelines could be applied by global clinicians; 3) an online network of mental health professionals who provided direct feedback on the ICD-11 to WHO (also known as the Global Clinical Practice Network, www.globalclinicalpractice.net) with over 16,000 members from 160 countries, and with the Russian Federation being in the top five most represented countries in the network; 4) clinic-based field studies that tested the reliability and clinical utility of the ICD-11 diagnostic guidelines; and 5) development and participation in training programs that prepare clinicians in implementing the diagnostic guidelines in clinical settings.

In these many ways, Russian clinicians have substantively and directly contributed to efforts to maximize the clinical 
usefulness, consistency, acceptability, and applicability of the ICD-11's mental, behavioural, and neurodevelopmental disorder guidelines. This substantial engagement of clinicians will conceivably facilitate the adoption and use of the guidelines by clinicians in the Russian Federation and other Russian-speaking countries, as the ICD-11 is implemented over the coming years.

\section{АннотАцИя}

Всемирная организация здравоохранения (ВОЗ) официально утвердила очередную версию своей единой диагностической системы - Международную классификацию болезней и проблем, связанных со здоровьем одиннадцатого пересмотра (МКБ-11). В настоящее время идет подготовка к внедрению МКБ-11. Разработка главы МКБ-11, посвященной психическим и поведенческим расстройствам и нарушениям нейропсихического развития, в соответствии с основными приоритетами ВОЗ в отношении клинической полезности, надежности и глобальной применимости диагностических указаний, потребовала крупномасштабной научно обоснованной программы исследований. В этой программе глобальных полевых исследований приняли участие специалисты в области психического здоровья со всего мира, в том числе из России.

В данной статье последовательно освещается существенная роль российских клиницистов на всех этапах разработки диагностических указаний для главы по психическим и поведенческим расстройствам и нарушениям нейропсихического развития, которые включали: 1) первоначальные полевые исследования, способствовавшие формированию организационных принципов и общей структуры МКБ-11; 2) крупномасштабные онлайн исследования на основе заданных клинических случаев для оценки клинической полезности и точности указаний МКБ-11; 3) участие в онлайн сети специалистов в области охраны психического здоровья, созданной при содействии ВОЗ для проведения исследований по МКБ-11, также известной как Всемирная сеть клинической практики, www.globalclinicalpractice.net), объединяющей более 16000 членов из 160 стран (причем Российская Федерация входит в первые пять стран, наиболее представленных в данном сообществе); 4) собственно клинические полевые испытания надежности и клинической полезности диагностических указаний МКБ$11 ; 5)$ участие в разработке учебных программ, подготавливающих клиницистов к внедрению новой версии классификации в практических условиях.

Таким образом, российские специалисты внесли существенный и непосредственный вклад в процесс улучшения клинической полезности, приемлемости и применимости диагностических указаний МКБ-11 по психическим и поведенческим расстройствам и нарушениям нейропсихического развития. Ожидается, что это будет способствовать успешному внедрению МКБ-11 в Российской Федерации и других русскоязычных странах в ближайшие годы.

Key words: classification; ICD-11; WHO; mental disorder; clinical utility Ключевые слова: классификация; МКБ-11; психическое расстройство; клиническое применение

\section{INTRODUCTION}

On May 2019, the World Health Organization (WHO) approved the newest version of its global diagnostic classification system, the International Classification of Diseases and Related Health Problems (Eleventh Revision; ICD-11). Although implementation processes are still underway, the ICD-11 is considered as the official classification system of all 194 WHO Member States, including the Russian Federation. This approved statistical version of the ICD-11 features a chapter on Mental, Behavioural and Neurodevelopmental Disorders, whose development was led by the WHO's Department of Mental Health and Substance Abuse (MSD). The development of this chapter and the related Clinical Descriptions and Diagnostic Guidelines (CDDG) - a version of the ICD-11 chapter that provides comprehensive and detailed diagnostic guidance on mental, behavioural and neurodevelopmental disorders - was a decade-long, scientifically-rigorous process that involved mental health professionals from across the globe, with appreciable participation of clinicians from the Russian Federation and from other Russian-speaking countries. ${ }^{1-5}$ The 
substantive participation of mental health professionals from the Russian Federation, and those from across the globe, in developing the ICD-11 was essential in enabling the WHO to ensure that the ICD-11 diagnostic guidelines were in line with its three core priorities. ${ }^{2,6}$

The first priority was to enhance the clinical utility of the guidelines, which reflects their usefulness when applied in the clinical context (e.g., how easily clinicians can apply the guidelines, how well the guidelines fit real-life patients, and how clear and understandable they are to clinicians). Clinical utility is a particular focus, as the ICD has important clinical uses, such as serving as a framework for diagnosis and as a basis for development of guidance on clinical management and standards of practice as well as facilitating research into more effective treatments and prevention. Improved clinical utility is also arguably crucial to the broader public health uses of ICD to facilitate the accurate collection and tracking of health data, to monitor mortality and morbidity, to assess disease burden, and to hold WHO Member States accountable for addressing this burden.

The second core priority was to validate the clinical consistency or reliability of the guidelines, and the third priority was to maximize the applicability and acceptance of the diagnostic guidelines to clinicians working in diverse clinical, geographical, and cultural contexts around the world. In this way, the ICD-11 would serve as a relevant and useful tool that can be used by global mental health professionals upon its implementation. Ensuring that the ICD-11 adhered to these three core priorities prompted a global research program led by MSD, which substantively engaged scientists, clinicians, and researchers from across the globe. Here we specifically highlight the important contributions of Russian mental health professionals in the development and field testing of the ICD-11 guidelines for mental, behavioural, and neurodevelopmental disorders.

\section{FORMATIVE ICD-11 FIELD STUDIES}

First, clinicians from the Russian Federation contributed to the early formative field studies of the ICD-11,7-9 allowing them to provide WHO with important feedback and data, which influenced the overarching architecture and linear structure of the ICD-11 chapter on Mental, Behavioural and Neurodevelopmental Disorders. This included a study in which WHO collaborated with Member Societies of the World Psychiatric Association (WPA) 7 in order to assess global psychiatrists' attitudes regarding mental disorder classifications, such as what they considered to be the most important purpose of a classification system of mental disorders, how they conceptualized severity and the relationship between functional impairment and diagnosis, and their attitudes toward the inclusion of dimensionality in a classification system. The study was conducted in 19 languages, including Russian, allowing for the participation of 4,887 clinicians from 44 countries. A noteable number $(n=298)$ of study participants were members of the Russian Society of Psychiatrists, making the Russian Federation the fourth most represented country in the study sample. In this way, the overall structure and organization of the ICD-11 chapter on Mental, Behavioural and Neurodevelopmental disorders was influenced by feedback from Russian clinicians and others from around the world. ${ }^{7}$

\section{EVALUATIVE ICD-11 FIELD STUDIES}

A second notable way in which Russian clinicians contributed to the development of the ICD-11 is through their participation in WHO MSD's large-scale global program of evaluative field studies, which tested whether the proposed versions of the ICD-11 guidelines met the standards of clinical utility, reliability, and global applicability set by WHO. ${ }^{10}$ This research program was overseen by international experts with the relevant clinical and research experience to be able to provide scientific leadership throughout the ICD-11 field testing process. These experts formed the ICD-11 Field Studies Coordinating Group and included members from the Russian Federation (authors VK and MK). The international representation in this leadership body overseeing the field testing was one of the mechanisms through which WHO aimed at ensuring that the final ICD-11 guidelines would reflect a version that was most useful and applicable to clinicians working in diverse contexts around the world, including the Russian Federation. ${ }^{2}$

Global Clinical Practice Network as a platform for ICD-11 case-controlled field studies

The first subset of evaluative studies, through which Russian clinicians contributed to the ICD-11, used a case-controlled methodology to test how accurately clinicians could apply the proposed ICD-11 guidelines to standardized case vignettes and also captured their assessment of the clinical utility of the guidelines. ${ }^{11,12}$ 
These studies were implemented online via the WHO's Global Clinical Practice Network (GCPN). The GCPN is a disciplinarily, geographically, and lingually diverse practice-based research network devoted to mental health, composed of individual mental health professionals who have registered to participate in WHO field studies on ICD-11 and related areas of inquiry. ${ }^{13} \mathrm{As}$ of February 2021, the GCPN has over 16,000 members from 160 countries. Over a thousand members (about $80 \%$ of whom are psychiatrists, representing $6.3 \%$ of the total network) are Russian, thus placing the Russian Federation in the top five most represented countries in the network. The GCPN also includes Russian-speaking mental health professionals residing in 24 other countries. GCPN members have an average 19 years of professional experience ( $S D=10.8$; range 0 to 68 years), and $92 \%$ actively see patients and engage in clinical activities. As such, they serve as ideal participants with the relevant clinical experiences to contribute to the online casecontrolled studies that test whether the ICD-11 guidelines can be accurately applied in a clinically useful manner.

\section{Case-controlled field studies in Russia}

As part of this evaluative program of field studies, clinicians in the Russian Federation first participated in a comprehensive process of translating the ICD-11 guidelines into Russian. This process involved forward translation (English to Russian) by experts with relevant clinical training and content expertise to be able to capture the technical details and clinical terminology included in the guidelines. This was followed by a back-translation (Russian to English) conducted by other experts. Any areas of confusion or differences in translations were reconciled through a consensus process so that the final version of the Russian ICD-11 guidelines can best capture the clinical nuance intended by the WHO Working Groups and other global experts who developed them.

In this field-testing phase, hundreds of Russian and Russian-speaking mental health professionals participated in major ICD-11 case-controlled studies that cover many of the key mental disorder areas including mood disorders, schizophrenia or other primary psychotic disorders, anxiety or fear-related disorders, obsessivecompulsive or related disorders, and dissociative disorders. ${ }^{14-16}$ Russian mental health professionals demonstrated their special diagnostic opinions based on their own clinical traditions and nosological approaches. ${ }^{17}$
Additional case-controlled studies are expected to be implemented in such areas as personality disorders and substance use disorders.

Another related online study that looked into how clinicians used classification systems and technology was also done in Russian, ${ }^{18}$ enabling WHO to better understand how the ICD-11 would likely be eventually used in clinical practice (e.g., which ICD version(s) do clinicians use and how do they access this content). In turn, this allowed WHO to potentially plan for additional or supplemental resources on ICD-11, which could be made available to clinicians, thus facilitating the adoption and use of the new classification system in the Russian Federation and in other parts of the world.

\section{Clinic-based (ecological implementation) field studies in Russia}

A second subset of evaluative field studies that allowed Russian clinicians to provide further contributions to CDDG development involved clinic-based field studies (also referred to as "ecological implementation" field studies), which tested how reliably the ICD-11 guidelines could be applied to real patients in natural clinical settings across the world., ${ }^{2,11}$ This study also examined clinicians' ratings of the utility of the guidelines when applied to patients in the clinical context, rather than the standardized cases as was done with the online casecontrolled studies. ${ }^{19}$

Clinicians at two study sites in the Russian Federation (Moscow Research Institute of Psychiatry and the First St. Petersburg City Mental Hospital named after PP Kaschenko) participated in the clinic-based study protocol, which specifically tested the reliability of the ICD-11 diagnostic guidelines relevant to psychotic, mood, anxiety, and stress disorders as applied to adult patients. Results demonstrated high ratings of clinical utility and other implementation characteristics of the guidelines..$^{19,20}$ Data from these studies were used to further improve the guidelines by identifying potential areas that require clarity or elaboration. In doing so, the improved guidelines can be more reliably and consistently applied in clinical practice in the Russian Federation, and across the world.

\section{ICD-11 TRAINING ACTIVITIES IN RUSSIA: EXPERIENCE AND FUTURE INITIATIVES}

With the participation of Russian clinicians and mental health professionals from around the world in the 
development and testing of the ICD-11 guidelines for mental, behavioural, and neurodevelopmental disorders, the CDDG is now close to being finalized and made broadly available. A next key step in the adoption of the ICD-11 is to train clinicians on the guidelines so that they are prepared to effectively use them in clinical practice when the ICD-11 is fully implemented. In-person trainings, led by world experts who had leadership roles in the ICD-11's development, such as members of the Field Studies Coordinating Group, have already taken place globally at scientific meetings or via webinars hosted by professional societies, such as the WPA and the European Psychiatric Association (EPA), and at WHO Collaborating Centers and other affiliated clinical or research institutions around the world. The objectives of these trainings are to orient clinicians regarding key principles, scientific foundations, and innovations introduced in the CDDG; to give clinicians in-depth knowledge of the guidelines and provide clinically-relevant rationales for the ICD-11's diagnostic approach, especially in areas where there may be noticeable differences with the ICD-10; and to expand clinicians' knowledge about psychopathology and the ICD-11 diagnostic classification. Trainings encourage active participation, provide an opportunity for clinicians to apply their knowledge of the ICD-11 guidelines to standardized cases, and offer clinicians the space in which to discuss and clarify diagnostic dilemmas and questions about the guidelines with both training facilitators and other colleagues in attendance. In the Russian Federation, the ICD-11 training activities have been ongoing, with the first programs linked to training clinicians who participated in the clinic-based reliability field studies of the ICD-11. Trainings have also been conducted through workshops as part of several local and national conferences and symposia throughout the Russian Federation.

The first workshop in Moscow was organized in May 2019 under the auspices of Professor George Kostyuk, Chief Expert in Psychiatry of the Moscow Healthcare Department, with the assistance of author MK, and led by authors GMR, KMP, and Professor/Past President of the EPA Dr. Wolfgang Gaebel. The program of this two-day training focused on the new ICD-11 diagnostic guidelines and key changes for several areas, namely, schizophrenia or other psychotic disorders, mood disorders, obsessivecompulsive disorders, anxiety or fear-related disorders, and disorders specifically associated with stress and personality disorders, followed by the application of new knowledge to standardized cases.

The workshop was held at the Civic Chamber of the Russian Federation in Moscow, conducted in English with simultaneous translation, and was attended by 144 Russian clinicians from 27 cities from diverse regions of the Russian Federation. Attendees included senior specialists or opinion leaders in psychiatry, such as chief doctors, directors, and the heads of departments at research or clinical institutions across the country, as well as postdoctoral trainees or medical residents. Qualitative data collected at the end of the workshop validated that Russian clinicians found the training valuable and that they were willing to serve as ambassadors of the ICD-11 by themselves facilitating broader training and adoption of the ICD-11 guidelines in Russia. The participants also mentioned the necessity of such events in supporting Russian clinicians as they implement the ICD-11 into clinical practice, with an emphasis on the need to consider the ICD-11 diagnostic approaches within the context of Russian clinical traditions. These data will be used to strengthen future training programs, such as the development of online ICD-11 trainings that are currently being pilot-tested and finalized for broader access.

\section{CONCLUSION}

As is evident, mental health professionals from the Russian Federation have played a substantive role in many key phases of the ICD-11's development. Not only have Russian specialists served on the ICD-11 scientific leadership group that guided the ICD-11 field testing process, but thousands of Russian clinicians working in diverse contexts all across the Russian Federation have participated in WHO MSD's large-scale program of global field studies. In this way, Russian clinicians have directly contributed to efforts to maximize the clinical utility, reliability, acceptability, and applicability of the CDDG guidelines. Such efforts can conceivably facilitate the adoption and use of the guidelines by clinicians in the Russian Federation and other Russian-speaking countries as the ICD-11 is implemented over the coming years.

Authors contribution: Tahilia J. Rebello: conception, design and writing of article, analysis and interpretation of data, leadership of studies mentioned in article; Maya A. Kulygina: conception, design and writing of article, leadership of studies mentioned in article; 
Valery N. Krasnov: review and final approval of article, leadership of studies mentioned in article; Kathleen $\mathrm{M}$. Pike: article review and leadership of studies mentioned in article; Geoffrey M. Reed: article writing, review and final approval of article, leadership of studies mentioned in article.

Fundling: The research was carried out without additional funding.

Conflict of interests: The authors report no conflicts of interest.

\section{Correspondence to:}

\section{Tahilia J. Rebello, Ph.D}

tahilia.rebello@nyspi.columbia.edu

\section{For citation:}

Rebello TJ, Kulygina MA, Krasnov VN, Pike KM, Reed GM. Engagement of Russian mental health professionals in the development of WHO's ICD-11. Consortium Psychiatricum. 2021;2(2):17-22. doi:10.17816/CP79

\section{References}

1. First MB, Reed GM, Hyman SE, Saxena S. The development of the ICD-11 Clinical Descriptions and Diagnostic Guidelines for Mental and Behavioural Disorders. World Psychiatry. 2015;14(1):82-90. doi:10.1002/wps.20189

2. Reed G, Rebello T, Saxena S. Core considerations in the development of the world health organization's international classification of diseases, 11th Revision. Indian J Soc Psychiatry. 2018;34(5):5. doi:10.4103/ijsp.ijsp_43_18

3. Reed GM, First MB, Kogan CS, et al. Innovations and changes in the ICD-11 classification of mental, behavioural and neurodevelopmental disorders. World Psychiatry. 2019;18(1):3-19. doi:10.1002/wps.20611

4. Clark LA, Cuthbert B, Lewis-Fernandez R, Narrow WE, Reed GM Three Approaches to Understanding and Classifying Mental Disorder: ICD-11, DSM-5, and the National Institute of Mental Health's Research Domain Criteria (RDoC). Psychol Sci Public Interest. 2017;18(2):72-145. doi:10.1177/1529100617727266

5. Stein DJ, Szatmari P, Gaebel W, et al. Mental, behavioral and neurodevelopmental disorders in the ICD-11: an international perspective on key changes and controversies. BMC Med. 2020;18(1):21. doi:10.1186/s12916-020-1495-2

6. International Advisory Group for the Revision of ICDM, Behavioural D. A conceptual framework for the revision of the ICD-10 classification of mental and behavioural disorders. World Psychiatry. 2011;10(2):86-92. doi:10.1002/j.2051-5545.2011.tb00022.x
7. Reed GM, Mendonca Correia J, Esparza P, Saxena S, Maj M. The WPA-WHO Global Survey of Psychiatrists' Attitudes Towards Mental Disorders Classification. World Psychiatry. 2011;10(2):118-131. doi:10.1002/j.2051-5545.2011.tb00034.x

8. Evans SC, Reed GM, Roberts MC, et al. Psychologists' perspectives on the diagnostic classification of mental disorders: results from the WHO-IUPsyS Global Survey. Int J Psychol. 2013;48(3):177-193. doi:10.1080/00207594. 2013.804189

9. Reed GM, Roberts MC, Keeley J, et al. Mental health professionals' natural taxonomies of mental disorders: implications for the clinical utility of the ICD-11 and the DSM-5. J Clin Psychol. 2013;69(12):1191-1212. doi:10.1002/jclp.22031

10. Kulygina MA, Krasnov VN. On conducting field trials of the new version of the International Statistical Classification of Diseases and Problems Related to Health. Article in Russian. Rossiskii psichiatricheskii zshurnal. 2018;(3):4-9

11. Evans SC, Roberts MC, Keeley JW, et al. Vignette methodologies for studying clinicians' decision-making: Validity, utility, and application in ICD-11 field studies. Int J Clin Health Psychol. 2015;15(2):160-170. doi:10.1016/j.ijchp.2014.12.001

12. Keeley JW, Reed GM, Roberts MC, et al. Developing a science of clinical utility in diagnostic classification systems field study strategies for ICD-11 mental and behavioral disorders. Am Psychol. 2016;71(1):3-16. doi:10.1037/a0039972

13. Reed GM, Rebello TJ, Pike KM, et al. WHO's Global Clinical Practice Network for mental health. Lancet Psychiatry. 2015;2(5):379-380. doi:10.1016/s2215-0366(15)00183-2

14. Rebello TJ, Keeley JW, Kogan CS, et al. Anxiety and Fear-Related Disorders in the ICD-11: Results from a Global Case-controlled Field Study. Arch Med Res. 2019;50(8):490-501. doi:10.1016/j. arcmed.2019.12.012

15. Kogan CS, Stein DJ, Rebello TJ, et al. Accuracy of diagnostic judgments using ICD-11 vs. ICD-10 diagnostic guidelines for obsessive-compulsive and related disorders. J Affect Disord. 2020;273:328-340. doi:10.1016/j.jad.2020.03.103

16. Peterson DL, Webb CA, Keeley JW, et al. The reliability and clinical utility of ICD-11 schizoaffective disorder: A field trial. Schizophr Res. 2019;208:235-241. doi:10.1016/j.schres.2019.02.011

17. Kulygina M, Krasnov V, Ponizovskiy P, Keeley J, Reed G. ICD11 Psychotic Disorders: Preliminary Results of the Casecontrolled Studies and the Russian Opinion. Eur Psychiatry. 2020;41(S1):S227-S227. doi:10.1016/j.eurpsy.2017.01.2227

18. First MB, Rebello TJ, Keeley JW, et al. Do mental health professionals use diagnostic classifications the way we think they do? A global survey. World Psychiatry. 2018;17(2):187-195. doi:10.1002/wps.20525

19. Reed GM, Sharan P, Rebello TJ, et al. The ICD-11 developmental field study of reliability of diagnoses of high-burden mental disorders: results among adult patients in mental health settings of 13 countries. World Psychiatry. 2018;17(2):174-186. doi:10.1002/wps.20524

20. Reed GM, Keeley JW, Rebello TJ, et al. Clinical utility of ICD11 diagnostic guidelines for high-burden mental disorders: results from mental health settings in 13 countries. World Psychiatry. 2018;17(3):306-315. doi:10.1002/wps.20581 